DOI: https://doi.org/10.15407/kvt199.01.059

UDC 004.891.3

GRITSENKO V.I., Corresponding Member of NAS of Ukraine, Director of International Research and Training Center for Information Technologies and Systems of the National Academy of Sciences of Ukraine and Ministry of Education and Science of Ukraine e-mail: vig@irtc.org.ua

FAINZILBERG L.S., DSc. (Engineering), Professor, Chief Researcher of the Department of Intelligent Automatic Systems e-mail: fainzilberg@gmail.com International Research and Training Center for Information Technologies and Systems of the National Academy of Sciences of Ukraine and of Ministry of Education and Science of Ukraine, 40, Acad. Glushkov av., Kyiv, 03187, Ukraine

\title{
CURRENT STATE AND PROSPECTS FOR THE DEVELOPMENT OF DIGITAL MEDICINE
}

Introduction. According to the definition of the International Society of Digital Medicine, digital medicine is a field of science in which scientists strive to explain previously incomprehensible pathophysiological phenomena in the human body and to explore new medical procedures using modern digital technologies to improve the quality of human life.

The purpose of the article is to provide brief information about the current state and prospects for the development of digital medicine.

Methods. The analysis of the main directions of digital medicine is done. Basic definitions of the concepts "Intelligent IT signal processing" and "Effective computational procedure" are formulated. The role of intelligent IT in digital medicine is demonstrated on the example of fasegraphy method.

Results. Existing methods and means of digital medicine are used for diagnosis, treatment, rehabilitation, as well as to restore the lost functions of the patient (vision, hearing, movement). Such technologies make it possible not only to free medical workers from solving routine tasks, but also to increase the efficiency of performing surgical operations, radiation therapy and a number of other tasks of practical medicine.

Unlike traditional IT, based on procedures for processing numerical data, intelligent IT operate with generalized concepts (images) that provide more complete information about the external environment, and the analysis of such images generates a holistic picture of the phenomena studied. 
Within the framework of the algorithmic approach, the construction of intelligent IT for solving the problems of digital medicine requires the active participation of a technology developer, who, using his natural intelligence, creates effective procedures for extracting diagnostic information from real data under disturbances.

Conclusions. Intelligent IT with the properties of natural intelligence (adaptation, generalization, learning, etc.) play an important role in expanding the functional capabilities and increasing the effectiveness of digital medicine.

Keywords: digital medicine, intelligent IT, efficient computing procedures.

\section{INTRODUCTION}

In the early $60^{\mathrm{s}}$ of the last century, a new scientific direction was formed - biological and medical cybernetics, which has come a long way in the development of its own mathematical, instrumental and informational methods of gaining knowledge about living complex systems [1-3].

Subsequently, on the basis of the studies, mathematical models of both individual organs in normal and pathological conditions, and mathematical models focused on the diagnosis, prognosis and treatment of various diseases were created. Much attention was also paid to automation of organizational and managerial tasks in clinics and health authorities.

Noting the undoubted importance of these results, it should be recognized, however, that at the initial stage of development biological and medical cybernetics did not provide an effective solution to a number of problems [4]. In particular, it was not possible to create conditions for mass preventive examinations, which provided the identification of dangerous diseases in the early stages, to reduce the cost of medical services, to ensure their accessibility to the general public, bringing diagnostic and treatment tools closer to patients.

It is clear that these problems could not be overcome only by minor modifications and simplification of clinical use devices. It turned out that the development of simple and reliable personalized medical devices requires the use of new approaches to information processing and specific methods for providing processing results to a user who does not have special medical knowledge [5].

The situation has changed dramatically with the advent of a new class of information technology (IT) - intelligent IT, which implements elements of natural intelligence. Unlike traditional ones, such technologies operate with generalized concepts - images, the analysis of which gives rise to a more complete and holistic picture of the phenomena studied, which allows to increase the reliability of decisions made.

The use of intelligent IT has led to a new healthcare paradigm — digital medicine.

The purpose of the article is to provide brief information about the current state and prospects for the development of digital medicine. 


\section{BASIC DIRECTIONS OF DIGITAL MEDICINE}

The concept of "digital medicine" should not be equated with any medical device built on the elements of digital computer technology. For example, in medical practice digital electrocardiographs are widely used, which implement traditional diagnostic algorithms based on the many years of experience of cardiologists to visually evaluate an electrocardiogram (ECG).

Of course, the use of such electrocardiographs facilitates simplifies the work of medical personnel and reduces the time to obtain diagnostic results. However, in our opinion, digital electrocardiographs that implement only traditional approaches to ECG processing should not be classified as digital medicine products, since they did not lead to the achievement of the main goal - to increase the reliability of diagnostic results.

Let us give a general description of the tasks that digital medicine is oriented to.

According to the definition of the International Society of Digital Medicine [7], digital medicine is a field of science in which scientists seek to explain previously incomprehensible pathophysiological phenomena in the human body and to explore new medical procedures using modern digital technologies to improve the quality of human life.

The introduction of digital technologies in medicine opens up enormous prospects, allowing significantly improving the quality of medical care and fundamentally change the approach to early diagnosis and treatment of dangerous diseases, as well as innovative rehabilitation technologies to restore the functions lost as a result of diseases [8].

In recent decades, there has been a rapid development of new digital technologies for the rehabilitation of patients suffering from neurological disorders, which have several advantages over conventional approaches, allowing you to adjust the intensity and dose of the rehabilitation procedure depending on the individual characteristics of the body of a particular patient [9].

The original means of this area - the TRENAR ${ }^{\circledR}$ series devices were developed at the International Research and Training Center for Information Technologies and Systems of the NAS of Ukraine and MES of Ukraine (follow IRTC ITS) [10]. The devices implement the technology of constructing an electronic image of movement, based on the registration of signals from a healthy organ (for example, a healthy hand) with the subsequent formation of electrostimulating impulses to a damaged limb (Fig. 1).
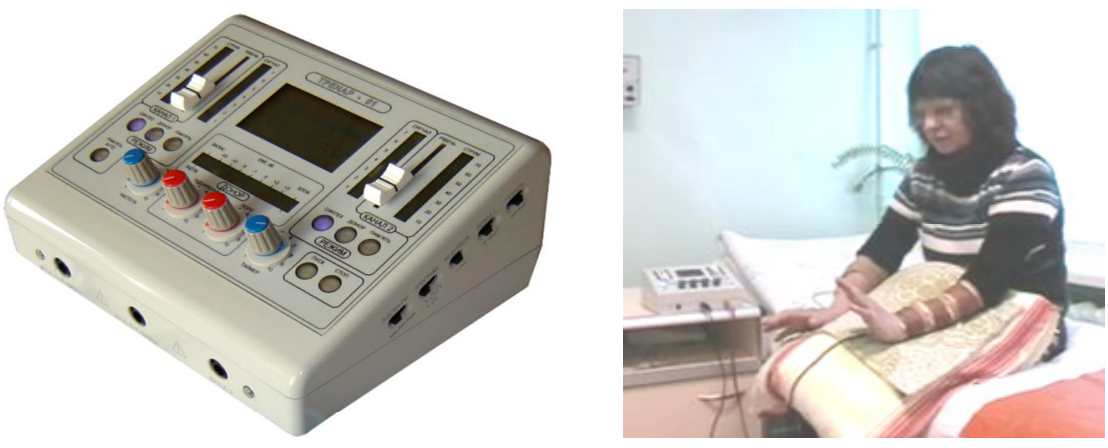

Fig. 1. TRENAR-01 device: the appearance of the device (left); rehabilitation technology (right) 
An important place in digital medicine programs is given to the development of special tools for patients who, for one reason or another, cannot fully restore their natural physiological functions - vision, hearing, movement, etc. The use of "intellectual" prostheses (Fig. 2) allows such patients not only to return to a normal lifestyle, but also to work.

A special place in this direction is occupied by exoskeleton, which is an external wearable skeleton that allows people with paralysis of the lower extremities to walk (Fig. 3). Recent studies confirm the positive effect of the use of exoskeleton in patients with spinal cord injuries and brain stroke [11].

The rapid development of robotics and intelligent manipulators opens up new opportunities in many fields, including medicine [12]. According to the apt expression of D. Engelberger, who received the title of "father of robotics", the hospital is an ideal environment for using robots. Original scientific research aimed at creating an autonomous robot capable of navigating in the environment is being conducted at the IRTC ITS [13].

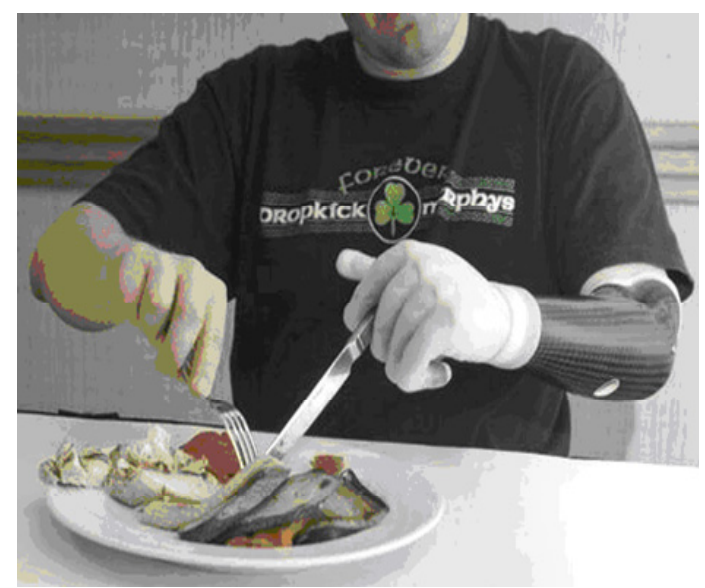

Fig. 2. Intelligent hand prosthesis
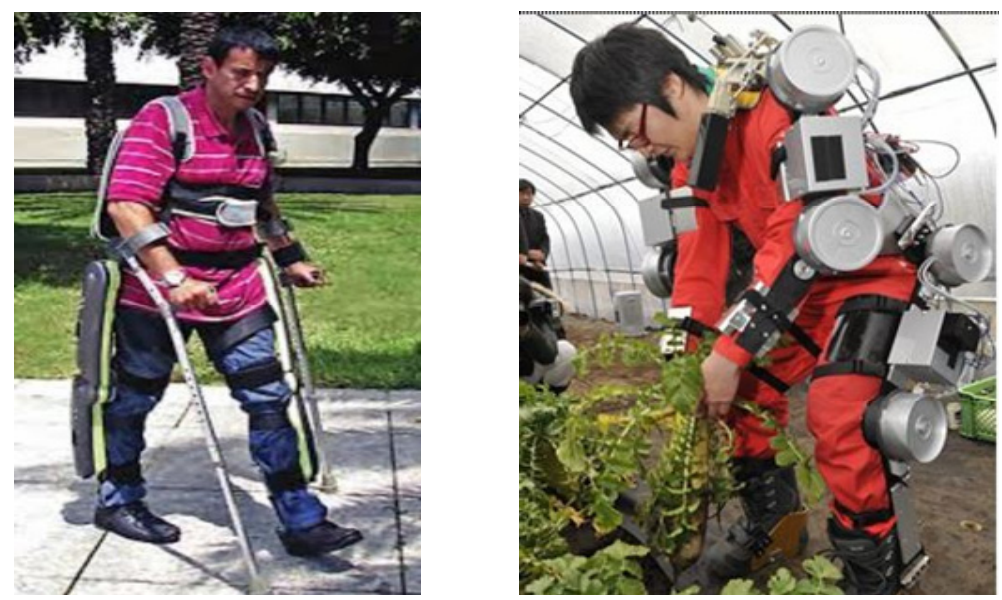

Fig. 3. Exoskeleton 
Let us give brief information about medical robots that are already used in practice [14] and are able to take on the solution of routine tasks of practical medicine.

A drug delivery robot has been successfully used at Veterans Affairs Medical Center [15]. The robot is able to move around the clinic, performing the work of the average medical worker, thereby solving the acute problem of the shortage of nurses (Fig. 4).

Surgical manipulators, in particular the well-known da Vinci system [16], can significantly reduce the incision and blood loss during surgery, increase the accuracy of movements, reduce both the time of the operation itself and the period of postoperative rehabilitation (Fig. 5).

A special video camera allows you to project on the screen a threedimensional picture of what is happening in the surgical field. It was the creation of the technology of three-dimensional vision that made it possible to implement the entire technology, since the usual two-dimensional image on the monitor screen does not allow the operator to accurately position the surgical instrument in space, especially in the "depth" of the image.

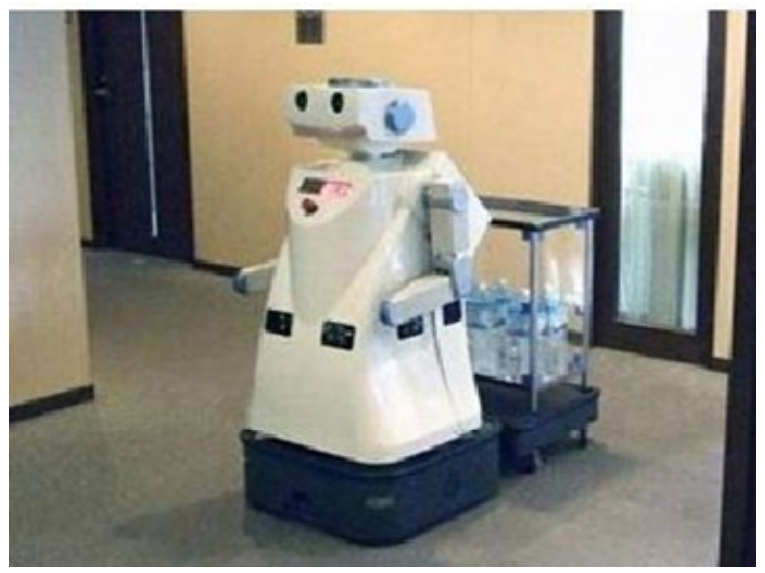

Fig. 4. The drug delivery robot

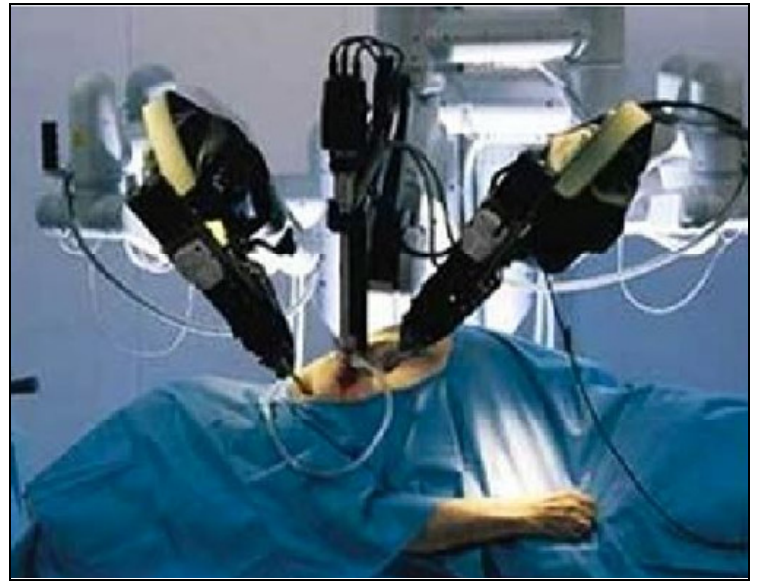

Fig. 5. Robot surgeon Da Vinci 
The main advantage of the "robot surgeon" is the creation of the possibility for the human surgeon to remotely micromanipulate with any instrument without the risk of making an accidental awkward movement, which are automatically blocked by the system.

The technique of modern surgery is constantly complicated. Therefore, the risk of negative consequences for the patient increases both during the operation itself and in the postoperative period. One of the possible ways to reduce such risks is computer planning of surgical interventions, which allows you to prepare a surgeon for possible errors and provide ways to prevent them. Such studies are conducted in Ukraine, in particular at the Kharkov National University of Radio Electronics [17].

The New Zealand "robot therapist", who, according to the operator's commands, can measure the pressure and temperature of the patient, determine the presence of wheezing in the lungs and perform a number of other operations, has also gained fame [18] (Fig. 6).

Thanks to the advent of robotic manipulators, radiation therapy for cancer patients received a new impetus. The high accuracy of the positioning of the ionizing radiation beam and the ability to follow a moving target are critical when irradiating a tumor on organs such as the brain, heart, or lungs.

The Cyberknife radiosurgical robot knife allows similar procedures to be performed automatically [19] (Fig. 7).

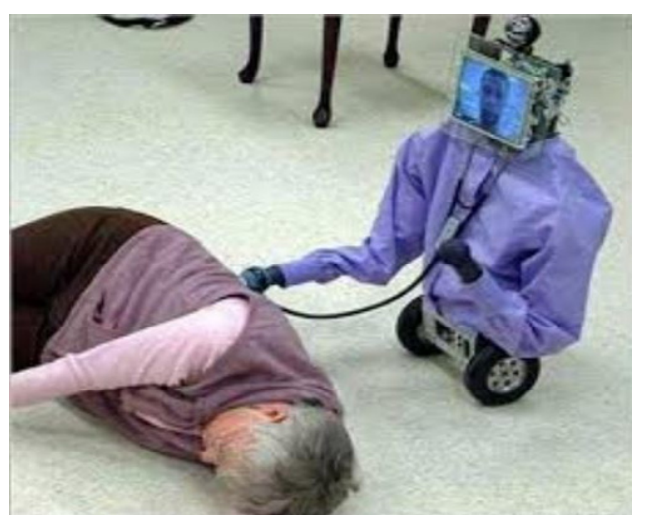

Fig. 6. New Zealand Therapist Robot

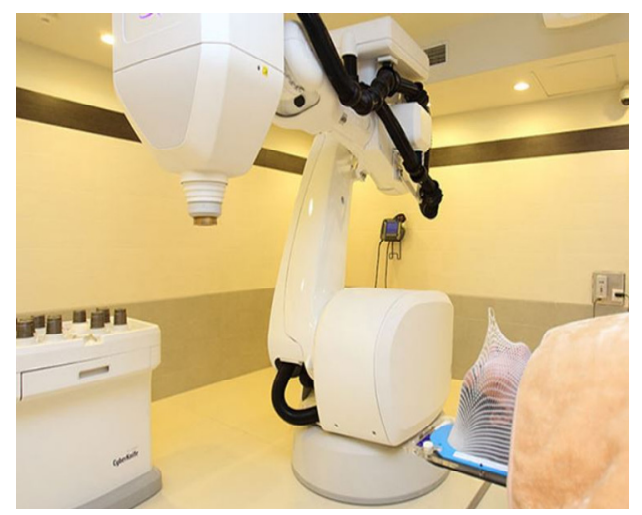

Fig. 7. Robot cyber knife 
The built-in synchronization system monitors the movements of the patient and his organs with the help of an X-ray camera and optical markers from the patient's skin, and a precisely directed beam of particles from a small linear accelerator destroys cancer cells without touching healthy tissue even with significant displacements of the patient.

Intelligent medical simulators are another important area in the field of digital medicine. With the help of such systems, novice doctors can obtain the necessary knowledge and improve their skills without causing problems to real patients.

For example, the Japanese company Kokoro has created a robot simulator "Simroid", which can respond to pain and mimic the corresponding reactions [20]. If the dentist makes a mistake, the virtual patient, who has special sensors in his mouth, grimaces, demonstrating discomfort and, if necessary, produce the necessary voice messages (Fig. 8).

The Norwegian company Laerdal has developed an intelligent simulator "SimMan 3G" [21], which can simulate various human reactions in an accident: characteristic heart pulsations, pathological lung movements, bowel contractions, etc. (Fig. 9). Such a system can be invaluable in training novice specialists working in disaster medicine services.

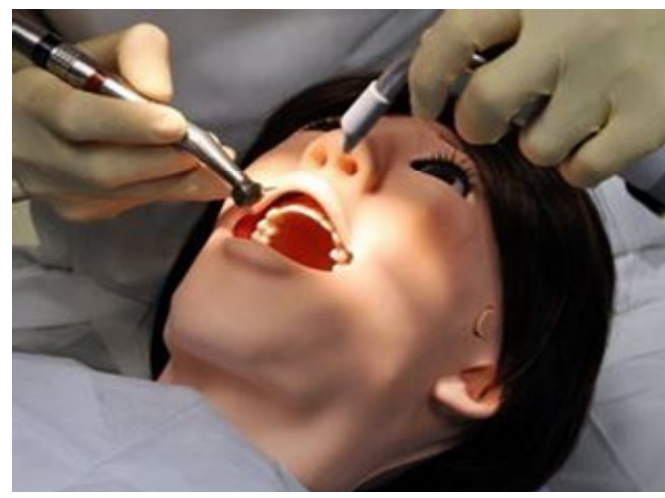

Fig. 8. Dental simulator

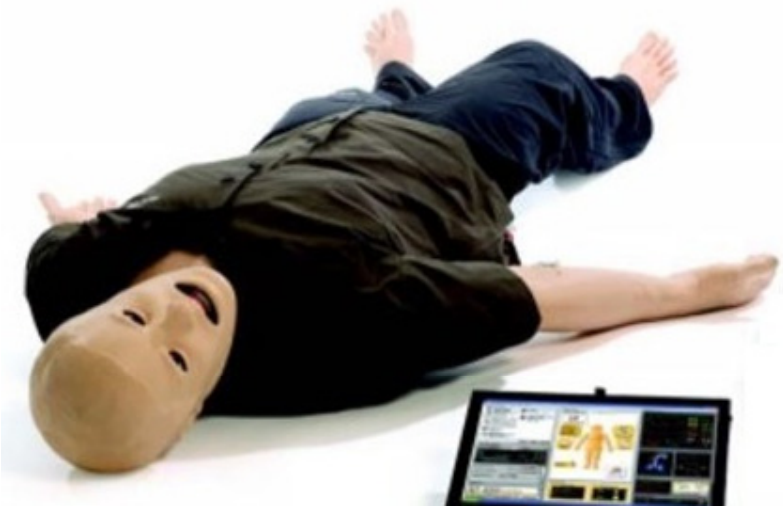

Fig. 9. Patient simulator SimMan 3G 
For visual training of methods for restorative breathing and spinal restoration techniques 3-D models of virtual instructors were developed at the IRTC ITS (Fig. 10) [22]. Unlike traditional videos in which real training is demonstrated, virtual instructors adapt the recovery technique to the individual characteristics of a particular user, taking into account the recommendations of a rehabilitation doctor.

The modern capabilities of telecommunication technologies that provide almost instantaneous data transmission over long distances, Cloud Service, which allow you to remotely store huge amounts of biomedical data, and Grid-systems oriented to distributed computing, laid the foundation of telemedicine - a new promising area of healthcare [23].

According to the definition of the US National Medical Laboratory for Medical Terms [24], telemedicine provides interactive advisory and diagnostic services via remote communication (Fig. 11).

Distinguish between synchronous telemedicine systems that can provide real-time interactive services for emergency consultations, training large groups of students and medical consultations, and asynchronous telemedicine systems that exchange previously saved medical images and signals for consultations when interactive communication with the patient is not required.

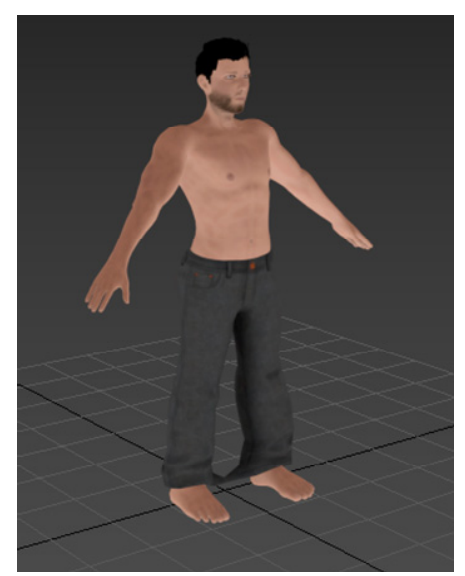

Fig. 10. Virtual trainer for learning of the restorative methods

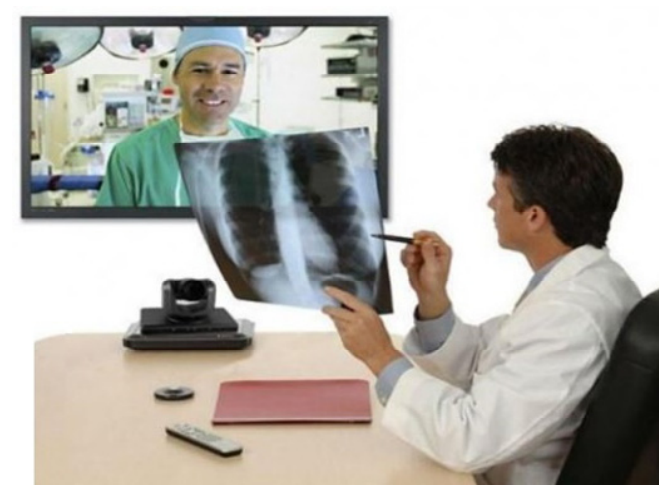

Fig. 11. Remote consultation 
Consultations with a doctor via the Internet, obtaining a sick-list or prescription in electronic form, storing all medical documents of a patient in his personal office may soon become a common practice for most patients.

Global Market Insights predicts that by 2024, the global market for digital healthcare technologies, including IT solutions and wearable devices, will exceed $\$ 379$ billion.

Telemedicine direction is developing intensively in Ukraine [25]. Suffice it to mention such developing telemedicine services as LEKARIS.com, which is a communication platform for doctors and patients. Its task is to translate the doctor's and patient's communication online, removing various barriers, thereby saving time on finding a doctor, consultations and personal receptions. Using the application, users can find the doctor of the desired specialization, urgently receive advice (messages, audio calls), schedule a consultation on a convenient day or make an appointment (Fig. 12).

The LIKI24 Internet service provides round-the-clock drug delivery throughout Ukraine (Fig. 13). The system analyzes the prices of products in more than 1300 pharmacies every minute, finds the minimum, takes the order and delivers the medicine to the patient. Due to the mathematical model, which calculates the optimal route, one courier makes up to 60 deliveries per day.

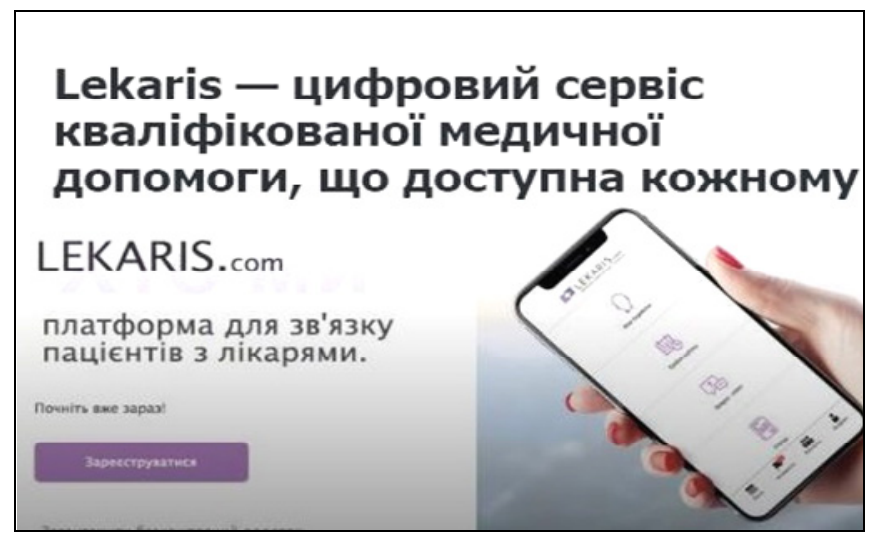

Fig. 12. LEKARIS.com service access window

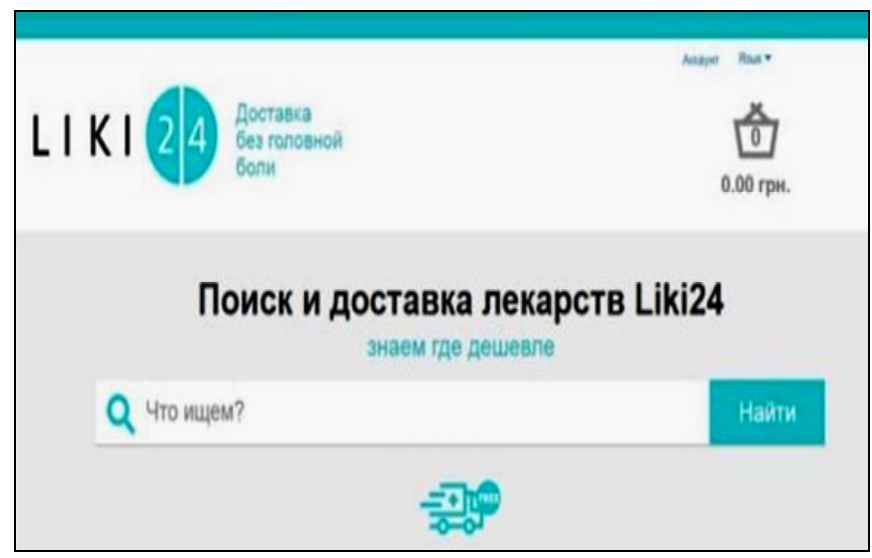

Fig. 13. LIKI24 service access window 
MYLAB service of Terra Lab Company is to integrate laboratory research, clinics, and patients into a single ecosystem (Fig. 14). Using this service, the doctor can obtain the necessary information about the laboratory market, create electronic appointments, indicating the alleged diagnosis, receive "tips" about the studies and track the status of the study in your account.

The brief and far from complete overview shows that at the present stage of the development of society, the existing methods and means of digital medicine are already actively used to solve practically important problems.

A natural question arises: what are the main promising areas of digital medicine that can be expected in the near future.

Analysis of available publications allows us to distinguish two such areas (Fig. 15), which aim to further increase the effectiveness of diagnosis and treatment based on the principles of personalized medicine: "to treat a specific patient rather than a disease" [26].

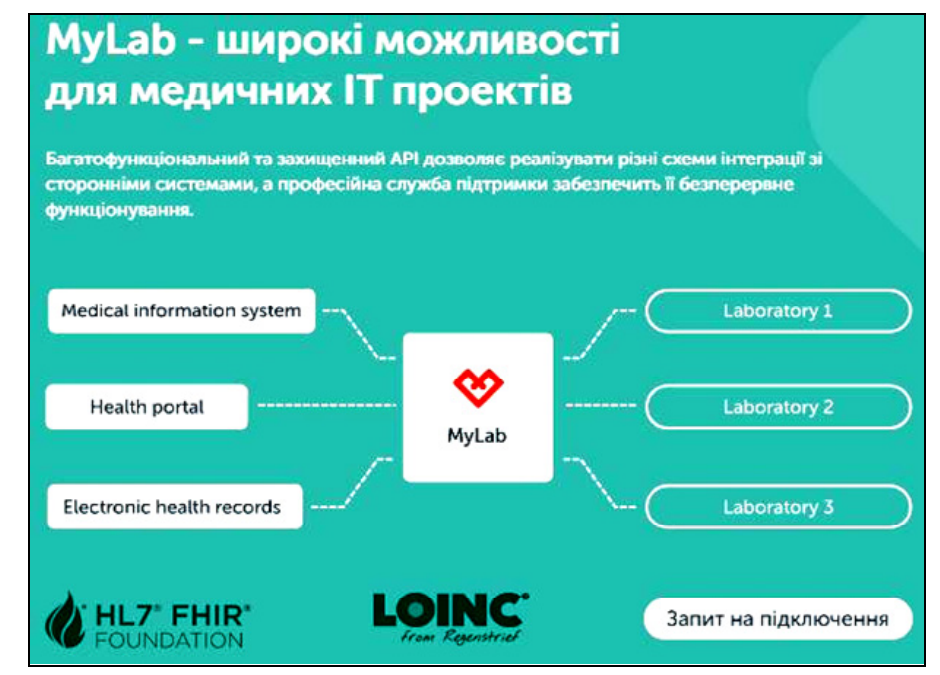

Fig. 14. MYLAB service access window

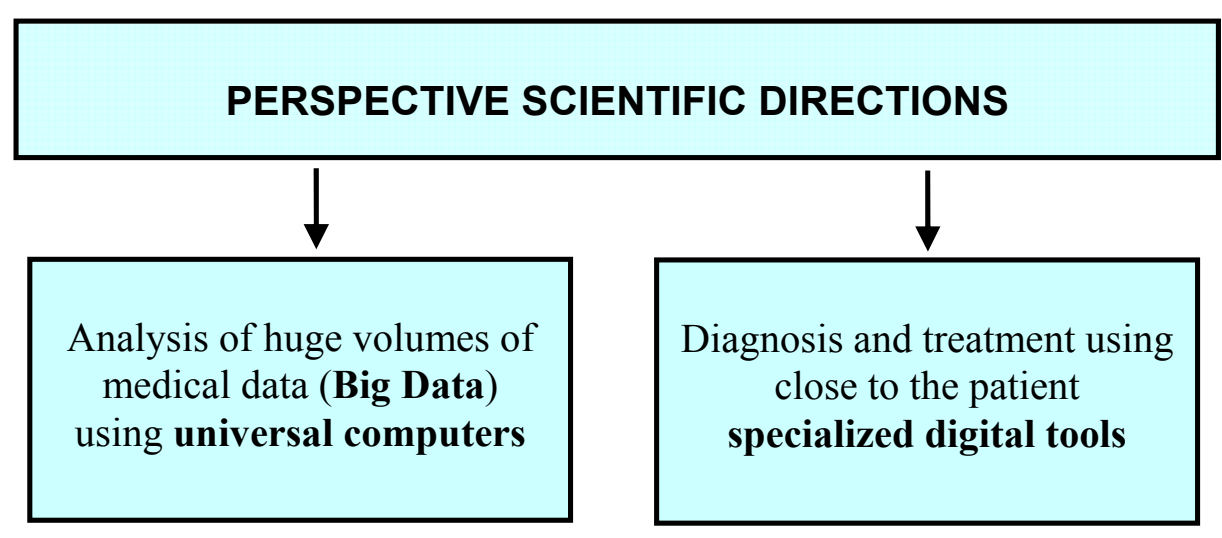

Fig. 15. The main directions of development of work in the field of digital medicine 
Both directions are developing rapidly. Given the importance of these areas, we will dwell on them in more detail.

By 2018, IBM released software products for building machine learning models, which, according to [27], allow, at the request of a doctor, to read about 200 million pages of text from the Internet in just three seconds and structure the information received.

The doctor can use such information to support the adoption of diagnostic decisions and choose the optimal treatment tactics for a particular patient based on a comparison of physiological parameters, symptoms of the medical history, DNA and other individual characteristics of his body with similar cases in world medical practice.

The company focuses further development of this direction [28] on solving such problems:

- providing an individual approach for the treatment of cancer patients;

- studying of mutations of cancer cells, leading to the emergence of resistance to the effects of drugs;

- searching for new, more effective, medications based on the analysis of the genetic data of hundreds of thousands of patients and healthy people.

Important results were obtained in the field of the second direction of work. According to the results of analytical studies [29], recently the market for medical devices has significantly changed its direction from complex systems of clinical use where relative stagnation is observed, to portable digital devices that patients can use on their own.

The relevance of this area is obvious. Severe illnesses often require inpatient treatment. But few people feel comfortable in the hospital. Hospitalization causes especially significant psychological trauma to the elderly and children. In addition, inpatient care suffers significant economic losses for both the patient and the public health system.

Recently, a new term has appeared - "home hospital". By this it is mean the program of constant supervision and rehabilitation at home of elderly people who have suffered serious illnesses - stroke, acute myocardial infarction, hip fracture, and the like. The patient is provided with medical care related to the constant monitoring of a family doctor, blood sampling, consultations of specialized specialists, medical injections, nurse services and more.

Let us show that the current level of development of inteligent IT already today can significantly increase the effectiveness of the "home hospital" by creating personalized means of processing physiological signals that the patient can independently use at home.

\section{INTELLIGENT INFORMATION TECHNOLOGIES IN DIGITAL MEDICINE}

Scientific research in the field of artificial intelligence (AI) began in the first half of the twentieth century, which laid the foundation for three areas (Fig. 16).

The founder of the algorithmic approach is rightfully considered the outstanding British mathematician Alan Mathison Turing. He set as goal to study the external side of human intelligence, in particular to analyze how a person performs calculations. These reflections in 1936 led to the creation of an abstract computer model, which was later called the Turing machine [30]. 


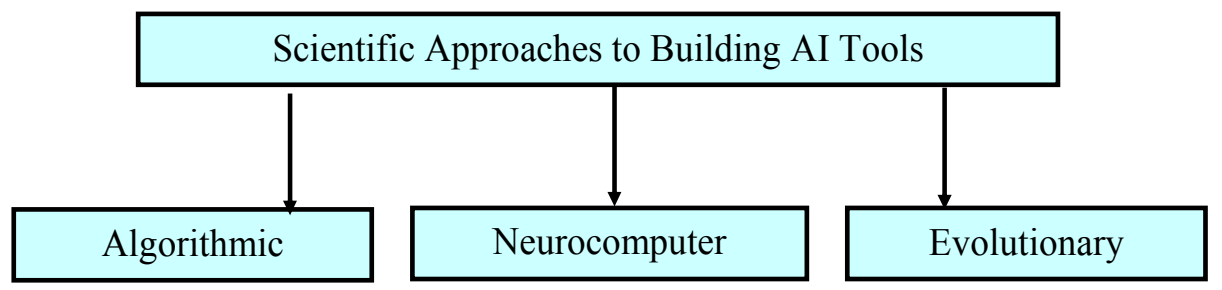

Fig. 16. The formed scientific directions of artificial intelligence

Despite the apparent simplicity, the Turing machine not only standardized the very concept of the algorithm, but also laid the foundation for the mathematical theory of complexity, the algorithmic theory of information, cryptography and many other scientific disciplines.

Discoverers of the neurocomputer approach were American physiologists Warren Sturgis McCulloch and Walter Pitts, who studied the internal organization of the human brain. Based on the study of brain cells, they first established that the process of thinking organizes by a complex combination of elementary logical operations such as AND, OR, NOT. As a result, in 1943, the simplest mathematical model of a neuron was proposed [31], which laid the foundation for neural network technologies.

And, finally, the formation of an evolutionary approach in the field of AI is associated with the name of the Italian mathematician Nils Barricelli, who set as goal to study the process of evolution of natural intelligence. By 1954, a model was proposed that served as the basis for a number of heuristic algorithms, in particular the so-called genetic algorithm [32], which actively uses the mechanisms of crossing, mutation, and inheritance, borrowed from Darwin's theory of the evolution of living nature.

For many years, these three areas developed in parallel and quite often unreasonably opposed to each other. However, the complexity of practical tasks requiring the use of AI tools led to a certain convergence of these approaches. Currently, scientific programs are actively being formed to create the so-called NBIC technologies based on the integration of nanotechnologies, biology, information technologies and cognitive sciences [33].

The priority direction of scientific and technological progress is the construction of intelligent IT, the concept of which was developed in Ukraine in the nineties of the last century [34]. Unlike traditional IT based on the procedures for processing numerical data, intelligent IT operate with generalized concepts (images) that provide more complete information about the external environment, and the analysis of such images generates a holistic picture of the phenomena studied.

The term intelligent IT is increasingly mentioned in the scientific and popular science literature. And this is no coincidence, since at the present stage of the development of society such technologies have a significant role in solving urgent applied problems, including in the field of digital medicine.

At the same time, the unreasonable application of these terms to application systems that are neither IT, nor even intelligent IT, can lead to the discrediting of these important scientific areas, as it has already been done more than once in the past, for example, to discrediting the term "Automated Control Systems". 
Since science begins with definitions, let us give a more or less rigorous formulation of the concept of "intelligent IT signal processing". To do this, we turn to the basic definition of the term "technology".

The word "technology" combines two terms: "Techno" (Greek "Téchnë" — art, skill, ability) and "Logic" (Greek "Logos" — science). Thus, in the general case, technology is the art of converting some raw material into a product (for example, iron ore into steel), and the science of technology is aimed at finding the most effective ways of such conversion.

This implies the following definition [35].

Definition 1. Intelligent IT for signal processing, including the physiological signal generated by a biological object is a set of computational procedures that have the properties of natural intelligence, which provide an effective transition from the observed signal (raw materials of the technology) to information about the current state of the object (technology product).

Formal and informal approaches to the construction of effective procedures that implement the individual stages of IT are possible. The first approach is based on the solution of the optimization problem: the computational procedure is constructed formally from the condition of minimum (maximum) of a certain criterion (super criterion) characterizing the effectiveness of a particular processing stage.

For example, the Bayesian classification is based on the minimum of the criterion, which represents the average risk of the decisions made, and the procedure for constructing the regression model is based on the minimum of the criterion, which is the standard error of the approximation of the experimental data by a function specified up to unknown parameters.

However, not all computational procedures can be built on the basis of a formal approach. It is far from always possible to express the effectiveness criterion for a particular stage of signal processing in the form of a convex function for which global optimization can be carried out. Other reasons for the limitations of the formal approach can be also pointed out.

In such situations, there is no choice but to build a computational procedure informally on the basis of intuition, and use the criterion only to assess its effectiveness.

Let $\mathfrak{I}_{0}$ be the a priori value of the criterion $\mathfrak{I}$ of an individual IT stage, which can be estimated (formally or by an expert) before using some computational procedure $\mathfrak{R}$, and let $\mathfrak{I}_{1}$ be the posterior value of the criterion $\mathfrak{I}$ estimated after using this procedure.

Then it is legitimate to introduce such definitions.

Definition 2. The procedure $\mathfrak{R}$ is effective if a strict inequality holds:

$$
\mathfrak{I}_{1}<\mathfrak{I}_{0} .
$$

Definition 3. The procedure $\mathfrak{R}^{(i)}$ is more effective than the procedure $\mathfrak{R}^{(j)}$ if for posterior values of the corresponding criteria the strict inequality holds

$$
\mathfrak{J}_{1}^{(i)}<\mathfrak{J}_{1}^{(j)}
$$

Thus, when informally building an effective computational procedure, it is not necessary at all to solve the optimization problem of finding a global minimum. 
Moreover, in accordance with the introduced definitions, the procedure remains effective even if it does not satisfy the local minimum of the criterion, but only allows to reduce the value of the criterion in comparison with its a priori value.

Of course, the formulated definitions can naturally be reformulated if the procedure $\mathfrak{R}$ is aimed at increasing the value of $\mathfrak{I}$.

Based on (1) and (2), the selection of a suitable procedure for the interactive synthesis of applied IT can be ensured by trial and error. For the practical implementation of this approach the tool system was developed at the IRTC ITS [36], which allows:

- conduct the necessary experiments to select and optimally configure computational procedures that implement individual stages of signal processing, including intelligent computational procedures;

- implement the technological chain of processing algorithms using readymade computing components of the tool environment itself;

- expand, if necessary, the composition of the components of the instrumental system (Fig. 17).

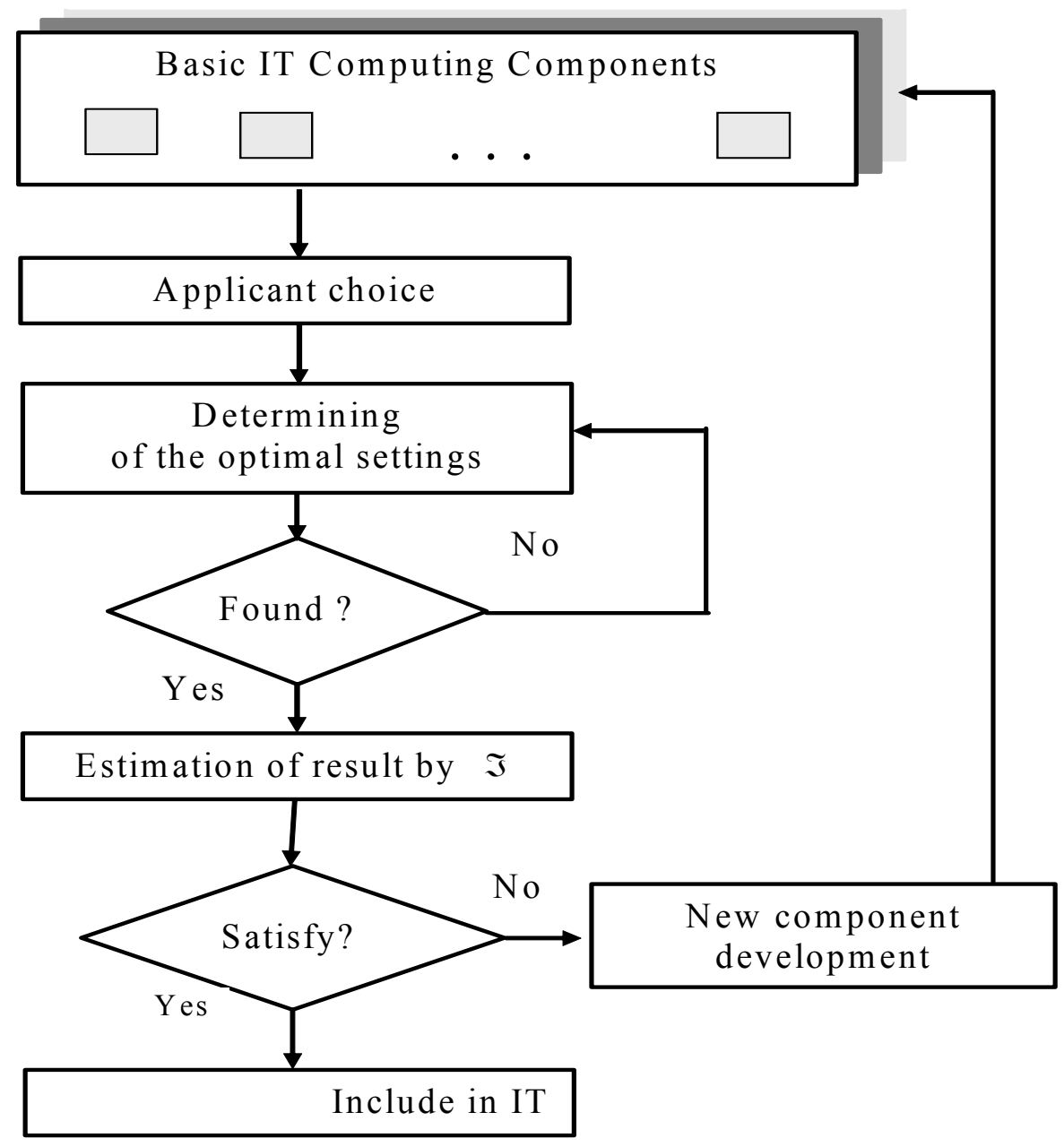

Fig. 17. The conceptual idea of interactive synthesis of IT 
The instrumental system made it possible to solve successfully a number of urgent applied problems, in particular, to create an original technology for processing electrocardiograms (ECG), which was called fasegraphy and is a vivid example of the successful use of intelligent IT in digital medicine [37,38].

The technology is implemented in the FASEGRAPH ${ }^{\circledR}$ complex, which received a certificate of state registration of medical devices with unlimited validity and is mass-produced. FASEGRAPH ${ }^{\circledR}$ consists of a microprocessor sensor that provides the convenience of registering the first standard lead ECG using finger electrodes, and a computer program that implements all stages of signal processing (Fig. 18).

Despite the fact that such single-channel ECG recorders (Home ECG monitors) are already quite widespread in the markets of medical equipment, FASE$\mathrm{GRAPH}^{\circledR}$ still has undoubted advantages compared to well-known counterparts such as Health Frontier (Canada), Win Health (Great Britain), Vitaphone (Germany), Cardiovit MT100 / 200/3 Schiller (Switzerland), Monebo (USA), J1 Portable ECG Monitor (China), CardioQVARK (Russia) and others, which allow you to control only the heart rate.

The main advantage of FASEGRAPH ${ }^{\circledR}$ is not the sensor itself, but high-tech information technology that implements the original method of processing ECG on the phase plane. Such an approach to ECG processing made it possible to expand the system of diagnostic features based on an assessment of the speed characteristics of the process, in particular, to implement for the first time a procedure for reliable determination of the indicator characterizing the symmetry of a repolarization fragment of an averaged phase trajectory.

Large-scale clinical trials have confirmed that this indicator increases the sensitivity and specificity of ECG diagnostics, even in cases where ECG analysis in 12 traditional leads is not informative. FASEGRAPH ${ }^{\circledR}$ is recommended by the Ministry of Health of Ukraine for coronary artery disease screening [39].

Fasegraphy is based on original computational procedures [40], which have the properties of natural intelligence, including properties:

- adaptations for the effective suppression of internal and external disturbances with incomplete a priori information about the characteristics of the interference;

- invariance of the shape of the reconstructed useful signal based on averaging of the distorted phase trajectories of the cardiac cycles of the observed ECG with possible time shifts (occurrence non-synchronism) of the same type of fragments;

- generalizations in the classification of typical and atypical ECG cycles in the absence of an analytical description of recognizable classes and the inability to determine generalizing features by machine learning methods;

- learning ability in the automatic assessment and constant correction of the personal norm of a particular patient to expand the functionality of the complex through the implementation of the idea of a personalized diagnosis of cardiac activity;

- sociability, which ensured the provision of test results in a convenient and accessible manner, taking into account the user's qualifications, in particular, the provision of information to a patient who does not have a medical education.

The experience in the development of fasegraphy has shown that, within the framework of the algorithmic approach, the construction of intelligent IT involves the active participation of a technology developer who, using his intelligence, creates effective computational procedures for extracting diagnostic information from real signals under disturbances (Fig. 19). 

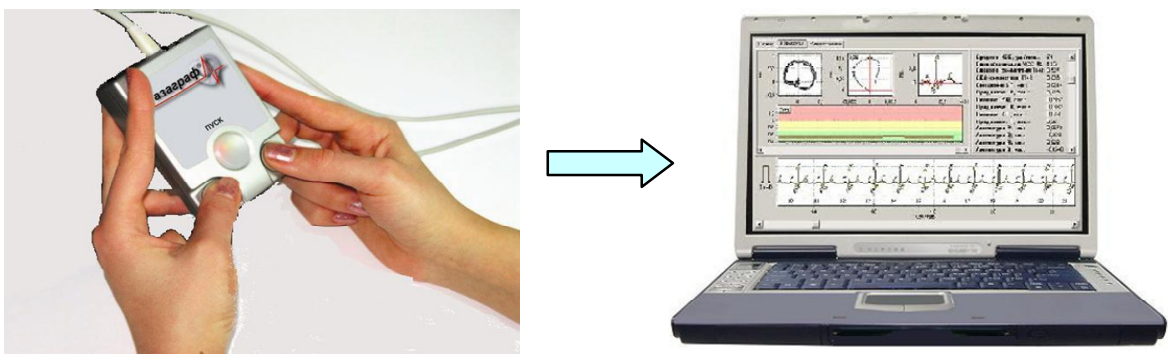

Fig. 18. FASEGRAPH $^{\circledR}$ complex

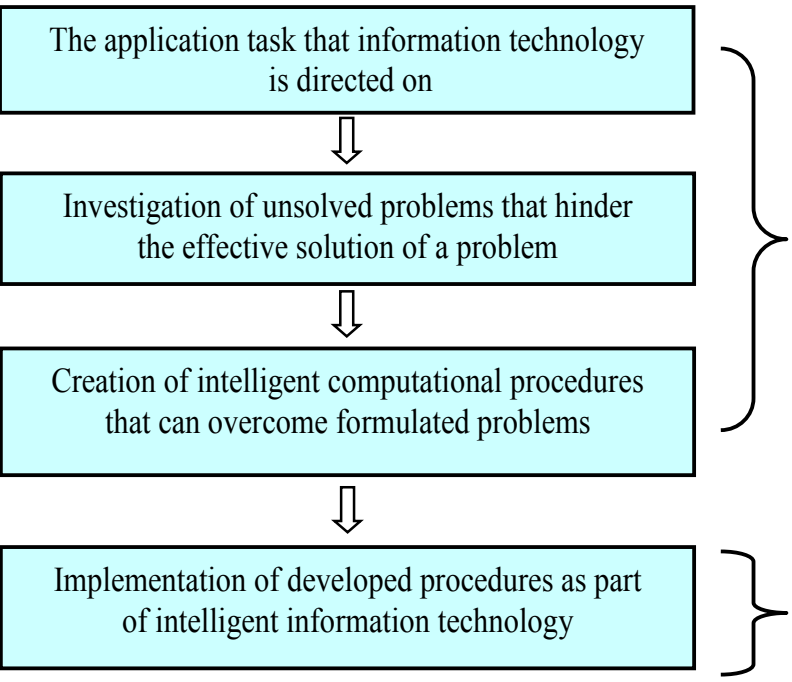

Natural Intelligence of

Technology Developer

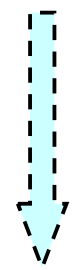

Artificial Intelligence

Fig. 19. Stages of building intelligent IT

FASEGRAPH $^{\circledR}$ has proven its effectiveness in various fields of application, including screening for coronary heart disease [41], in pediatric cardiology to assess cardiometabolic risk in adolescents, the functional state of children with diabetic cardiopathy, cardiorespiratory desynchronism, and the effect of motor activity in schoolchildren [42-46], in sports medicine for the rapid assessment of overtraining and the general functional level of highly qualified athletes [47], in the clinical setting for evaluating the effects of drugs during the drip of drugs to cardiological patients and the effectiveness of surgical interventions [48], when performing scientific research, including studying the effects of external fields on a person during solar activity, the harmful effects of smoking on the human body and the search for objective chrono-predictors carrying information about the level of threat to the patient [49].

FASEGRAPH $^{\circledR}$ occupies a special place in the market of medical equipment (Fig. 20). Before it appearance, the cardiological patient had only two possibilities: either use the home ECG monitors (smartphone gadgets), which in the best case allow diagnosing life-threatening cardiac arrhythmias, or conduct a complete traditional ECG examination in a medical facility using an expensive and not always affordable professional electrocardiograph. 


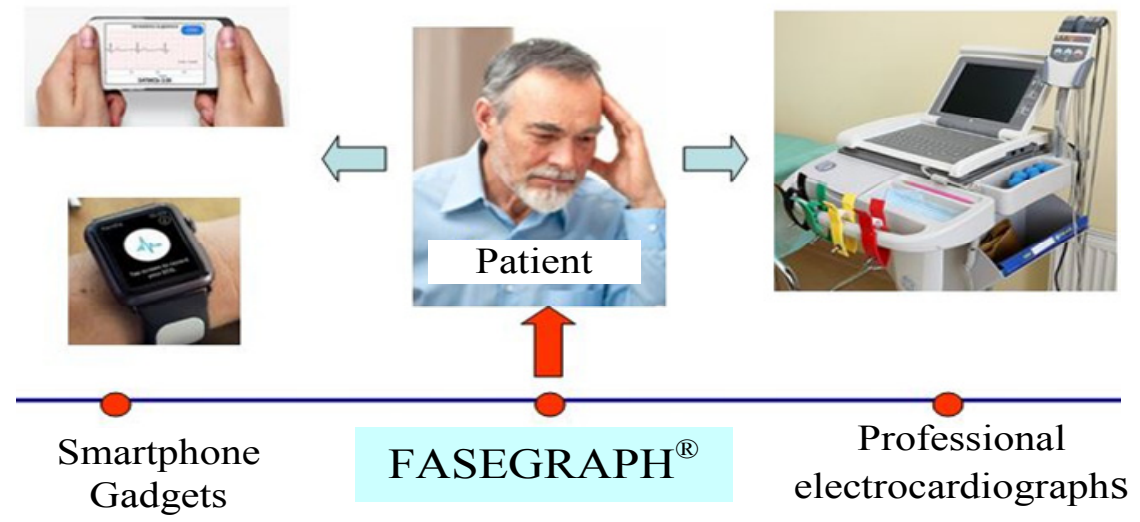

Fig. 20. The situation in the medical equipment market

The permanent use of FASEGRAPH ${ }^{\circledR}$ at home allows the patient:

- to optimize a way of life, reasonably distributing a mode of loadings and rest;

- to determine the need for additional intake of medications prescribed by a doctor;

- to evaluate possible dangerous deviations in the work of the heart from the personified norm;

- independently accumulate data over a long period of time for subsequent consultations with a doctor, which provides a more complete and reasonable assessment of the patient's functional state than episodic contact with a doctor using traditional clinical tools.

The mobile fasegraphy platform currently being developed, which provides for the implementation of technology elements on a smartphone, provides the opportunity not only to conduct operational testing in any conditions, but also to organize a virtual connection between a patient and a family doctor using Internet technologies [50-52].

Fasegraphy has opened the way to the construction of new methods for biometric identification of individuals based on the unique properties of ECG phase portraits [53-54].

The intelligent capabilities of phase printing are constantly being developed due to the inclusion of new program modules in FASEGRAPH ${ }^{\circledR}$, including modules for evaluating the randomness of the processed signal shape parameters [55], a phase portrait of permutation entropy, which confirmed the high sensitivity when evaluating subtle ECG changes under the influence of various factors, in particular, to detect the effect of electrical heart alternation, which is used by doctors as a predictor of sudden cardiac death [56], as well as to assess the tolerance to physical stress based on the regulatory patterns and their display in the form of cognitive graphic images [57].

Further development of fasegraphy involves the implementation of new promising approaches to the processing of cyclic signals, in particular, the method of displaying a signal in a multidimensional parameter space, which, using unified methodological principles, makes it possible to evaluate the randomness of the waveform, detect atypical cycles, interpret the signal, personify diagnostic solutions and economical coding of the signal when it transmission and storage [58,59], and 
the linguistic method of signal analysis and interpretation based on the calculation of the Levenshtein distance between codograms of real signals [60].

Preliminary studies have shown that intelligent computational of fasegraphy procedures allow you to create a new class of competitive medical devices, in particular, finger photoplethysmograph, which records the patient's pulse wave using the built-in smartphone camera without additional external signal sources [61], as well as an intelligent home blood pressure monitor with advanced functional opportunities.

\section{CONCLUSION}

An analysis of the available literature showed that at the present stage of the development of society, the existing means of digital medicine are used to solve many urgent problems of practical medicine, including in the diagnosis, treatment and restoration of lost functions. Such technologies make it possible not only to free medical workers from solving routine tasks, but also to increase the efficiency of performing surgical operations, radiation therapy and a number of other complex tasks.

Intelligent IT with the properties of natural intelligence (adaptation, generalization, learning, etc.) play an important role in expanding the functionality and increasing the effectiveness of digital medicine. Unlike traditional IT based on the procedures for processing numerical data, intelligent IT operate with generalized concepts (images) that provide more complete information about the external environment, and the analysis of such images generates a holistic picture of the phenomena studied.

Using the example of successful development of the fasegraphy method, it is shown that, within the framework of the algorithmic approach, the construction of intelligent IT for solving digital medicine problems involves the active participation of a technology developer who, using this natural intelligence, creates effective procedures for extracting diagnostic information from real data distorted by disturbances.

\section{REFERENCES}

1. Amosov N.M. Modeling complex systems. Kiev: Naukova Dumka, 1968. 87 p. (In Russian)

2. Anokhin P. K. Theory of a functional system. Advances in physiological sciences. 1970, Vol. 1, no. 1, pp. 19-54. (In Russian)

3. Grodins F.S. Control Theory and Biological Systems. New York: Columbia University Press, 1963, $179 \mathrm{p}$.

4. Gritsenko V.I. Digital medicine and information technology - cornerstones of healthcare for the future. Bulletin of NAS of Ukraine. 2016, no 5, pp. 41-43. (In Ukrainian).

5. Gritsenko V.I., Fainzilberg L.S. Personalized digital medicine - a step towards health. Bulletin of NAS of Ukraine. 2012, no 8, pp. 62-70. (In Ukrainian).

6. Gritsenko V.I., Fainzilberg L.S. Information technology FASEGRAPH ${ }^{\circledR}$ for the integrated assessment of the state of the cardiovascular system according by the phase portrait of the electrocardiogram. Doctor and information technology. 2013, no. 3, pp. 52-63. (In Russian).

7. Zhang S., Liao R., Alpert J.S., Kong J., Spetzger U., Milia P., et al. Digital Medicine: Emergence, Definition, Scope and Future. Digit Medicine. 2018, no. 4, pp. 1-4. DOI: 10.4103/digm.digm_9_18.

8. Kwakkel G., Kollen B., Lindeman E. Understanding the Pattern of Functional Recovery after Stroke: Facts and Theories. Restor Neurol Neurosci. 2004, no. 22, pp. 281-299. 
9. Lo A.C., Guarino P.D., Richards L.G., Haselkorn J.K., Wittenberg G.F., Federman D.G. et al. Robot Assisted Therapy for Long Term upper Limb Impairment after Stroke. The New England Journal of Medicine. 2010, Iss. 362, pp. 1772-1783. DOI: 10.1056/NEJMoa0911341.

10. Vovk M.I. Galyan E.B., Kutsyak A.A., Lauta A.D. Formation of an individual complex of control actions for the rehabilitation of movements and speech after a stroke. Kibernetika $i$ vyčislitel naâ tehnika. 2018, no. 3, pp. 43-63. (In Russian). DOI: https://doi.org/10.15407/kvt192.03.043.

11. Milia P., De Salvo F., Caserio M., Cope T., Weber P., Santella C. et al. Neurorehabilitation in Paraplegic Patients with an Active Powered Exoskeleton (Ekso). Digital Medicine. 2016, no. 2, pp. 163-168. DOI: 10.4103/digm.digm_51_16.

12. Michaud F., Salter T., Duquette A., Laplante J. Perspectives on Mobile Robots as Tools for Child Development and Pediatric Rehabilitation. Assistive Technology. 2007, Vol. 19, no. 1, pp. 21-36. https://doi.org/10.1080/10400435.2007.10131863

13. Sukhoruchkina O.N., Progonny N.V., Voronov M.A. Interpretation and use of measurements of a rangefinder sensor in control tasks of an autonomous mobile robot. Upravlâusie sistemy i mašiny. 2017, no. 1, pp. 26-34. (In Russian).

14. Kraevsky S.V., Rogatkin D.A. Medical robotics: the first steps of medical robots. Technologies of living systems. 2010, Vol. 7, no. 4, pp. 3-14. (In Russian).

15. Okie S. Robots Make the Rounds to Ease Hospitals' Costs. The Washington Post. 2002, no 3, p. A3.

16. Tarasova L. Da Vinci in tandem with the surgeon. Medical Herald. 2008, no. 8, pp. 435. (In Russian).

17. Avrunin O.G., Semenets V.V. To the question of determining the force characteristics of a field in magnetic stereotaxis systems. Radio engineering. 2001, no. 117, pp.121-124. (In Russian).

18. Wang Y., Butner S.E., Darzi A. The Developing Market for Medical Robotics. Proc. IEEE, Special issue "Medical Robotics". 2006, Vol. 94, no. 9, pp.1763-1770. DOI: 10.1109/JPROC.2006.880711.

19. Donnet A., Valade D., Régis J. Gamma Knife Treatment for Refractory Cluster Headache: Prospective Open Trial. Journal of Neurology, Neurosurgery and Psychiatry. 2005, no. 2, pp. 218-221. DOI: 10.1136/jnnp.2004.041202.

20. Simroid: Dentistry in the uncanny valley. URL: http://pinktentacle.com/2007/11/simroid-dentistry-in-the-uncanny-valley-video.

21. SimMan 3G. Patient Simulator Gets a Serious Upgrade. MedGadget internet journal of emerging medical technologies.

22. Fainzilberg L.S., Pomorskaya D.V. Information technology teaching the methods for the organism recovery at home conditions. Upravlâûsie sistemy $i$ mašiny. 2018, no 1, pp. 87-96. DOI: https://doi.org/10.15407/usim.2018.01.087.

23. Shaw D. Overview of Telehealth and Its Application to Cardiopulmonary Physical Therapy. Cardiopulmonary Physical Therapy Journal. 2009, Vol. 20, no. 2, pp. 13-18.

24. Telemedicine yesterday, today, tomorrow. Electronics: Science, Technology, Business. 2000, no. 2, pp. 62-65.

25. Digital medicine in Ukraine: overview of services. URL: https://ain.ua/ 2018/12/14/cifrovaya- medicina-v-ukraine-obzor-servisov/

26. Fainsilberg L.S. Digital medicine and intellectual information technology. Proc. of the First International Scientific and Practical Conference "Information Systems and Technologies in Medicine" (ISM-2018). Kharkiv: KNURE, Madrid Printing House, 2018, pp. 21-23.

27. Empowering Heroes, Transforming Health. URL: https://www.ibm.com/watson/health/

28. IBM Healthcare Technologies (In Russian). URL: http://cognitive.rbc.ru/health-tech.

29. Ambulatory Cardiac Monitoring: Avoiding Maturity through Technological Advancement. Market Engineering Research. Frost \& Sullivan, Meriland. 2008, no. 9, pp. 325.

30. Turing A.M. On Computable Numbers, with an Application to the Entscheidungs problem. Proceedings of the London Mathematical Society. 1937, Vol. 2, Iss. 42, pp. 230-265. 
31. McCulloch W.S., Pitts W. A Logical Calculus of the Ideas Immanent in Nervous Activity Bulletin of Marhematicak Biophysics. 1943, Vol. 5, pp. 115-143.

32. Nils Aall Barricelli N.A. Numerical Testing of Evolution Theories. Acta Biotheoretica. 1962, Vol. 16, Iss. 1-2, pp. 69-98.

33. Converging Technologies for Improving Human Performance: Nanotechnology, Biotechnology, Information Technology and Cognitive Science. Edited by Mihail C. Roco and William Sims Bainbridge. Dordrecht: Kluwer Academic Publishers (Springer), 2003, 482 p.

34. Gritsenko V.I. Intellectualization of information technologies. Science and Technology. Kiev: V.M. Glushkov Institute of Cybernetics. NAS of Ukraine, 1992, pp. 4-9. (In Ukrainian).

35. Fainsilberg L.S. Intellectual opportunities and prospects for the development of fasegraphy - the information technology for processing signals of complex shape. Kibernetika i vyčislitel 'naâ tehnika. 2016, Iss. 186, pp. 56-77. (In Russian).

36. Fainzilberg L.S. Interactive synthesis of information technologies for signal processing with localized information. Kibernetika $i$ vyčislitel 'naâ tehnika. 2017, Iss. 1 (187), pp. 11-29. (In Russian). DOI: doi.org/10.15407/kvt187.01.011

37. Fainsilberg L.S. Computer diagnostics by phase portrait of an electrocardiogram. Kyiv: Osvita of Ukraine, 2013, 191 p. (In Russian).

38. Fainsilberg L.S. Basics of fasegraphy. Kyiv: Osvita of Ukraine, 2017, 264 p. (In Russian).

39. Dyachuk D.D., Gritsenko V.I., Fainzilberg L.S., et al. The use of the method of fasegraphy in the screening of coronary artery disease. Methodological Recommendations of the Ministry of Health of Ukraine № 163.16 / 13.17. Kyiv: Ukrainian Center for Scientific Medical Information and Patent Licensing, 2017, 32 p. (In Ukrainian).

40. Fainzilberg L.S. Intelligent information technology for signal processing with localized information. Artificial Intelligence. 2018, no. 2, pp. 144-153. (In Russian).

41. Dyachuk D.D., Kravchenko A.N., Fainzilberg L.S., Stanislavskaya S.S., Korchinskaya Z.A., Orikhovskaya K.B., Pasko V.S., Mikhalev K.A. Screening of myocardial ischemia by the method of assessing the phase of repolarization. Ukrainian Cardiology Journal. 2016, no. 6, pp. 82-89. (In Russian).

42. Maydannik V.G., Khaitovich N.V., Fainzilberg L.S., Stepanov V.A., Vladimirova A.A., Misyura L.I. Symmetry of the T wave on the electrocardiogram as a marker of cardiometabolic risk in schoolchildren. International Journal of Pediatrics, Obstetrics and Gynecology. 2013. Vol. 4, no. 3, pp. 35-39. (In Russian).

43. Morozik A.A. Fainzilberg L.S. The diagnostic significance of the combined analysis of the electrocardiogram on the phase plane and heart rate variability in children with diabetic cardiopathy. International Journal of Pediatrics, Obstetrics and Gynecology. 2015, Vol. 7, no.1, pp. 11-17. (In Russian).

44. Morozik A.O., Maidannik V.G., Fainzilberg L.S. Informative properties of indicators of the phase of repolarization of single-channel electrocardiogram in children with diabetic cardiomyopathy. Endocrinology. 2018, Vol. 23, no. 1, pp. 74-82. (In Ukrainian).

45. Maydannik V.G., Fainzilberg L.S., Dukkart K.B., Morozik A.O., Kondratyuk A.S. Regulatory patterns in assessing the functional state of the body of children and adolescents with type 1 diabetes. Ukrainian magazine of child endocrinologist. 2018, no. 1, pp. 51-60. (In Russian)

46. Maydannik V.G., Fainzilberg L.S., Dukkart K.B., Morozik A.A., Kondratyuk A.S. A new approach to the analysis of the functional state of the body of children and adolescents with type 1 diabetes. Modern pediatrics. 2018, no. 2 (90), pp. 37-46. (In Russian).

47. Pavlichenko P.P. The influence of game load on the functional state of professional football players. Light Medicine and Biology. 2015, no. 1 (48), pp. 49-54. (In Russian).

48. Fainzilberg L.S. New Opportunities of Phasegraphy in Medical Practice. Science and Innovation. 2017, Vol. 13. Iss. 3, pp. 37-50. DOI: 10.15407/scine13.03.037.

49. Fainzilberg L.S. Evaluation of the effectiveness of the application of information technology FASEGRAPH ${ }^{\circledR}$ according to independent studies. Upravlâûsie sistemy i mašiny. 2014, no. 2, pp. 84-92. (In Russian).

50. Fainzilberg L.S. The technology for constructing a telemedicine system based on a generative model of generating an artificial ECG of a realistic form. Clinical computer science and telemedicine. 2012, Vol.8. Iss. 9, pp. 89-98. (In Russian). 
51. Fainzilberg L.S., Soroka T.V. Development of a telemedicine system for remote monitoring of cardiac activity based on the phasegraphic method. East European Journal of Advanced Technology. 2015, no. 6/9 (78), pp. 37-46. (In Russian). DOI: 10.15587/17294061.2015.55004.

52. Fainzilberg L.S., Soroka T.V. Mobile applications for the virtual interaction of a doctor and a patient with remote monitoring of cardiac activity. Kibernetika $i$ vyčislitel nâa tehnika. 2016, Iss. 184, pp. 8-24. (In Russian).

53. Fainzilberg L.S., Potapova T.P. Computer Analysis and Recognition of Cognitive Phase Space Electro-Cardio Graphic Image. In Proc. of the $6^{\text {th }}$ International Conference On Computer analysis of Images and Patterns (CAIP'95), , Prague, Czech Republic, 1995, pp. 668-673.

54. Fainzilberg L.S., Korchinska Z.A., Semergei M.O. Software-technical complex for research of a new method of biometric identification of a person by a phase portrait of an ECG. Forensic Bulletin. 2015, no. 1 (23), pp. 63-71. (In Ukrainian).

55. Fainzilberg L.S., Orikhovskaya K.B., Vakhovsky I.V. Assessment of the randomness of the fragments shape of a single-channel electrocardiogram. Kibernetika $i$ vyčislitel na $\hat{a}$ tehnika. 2016, Iss. 183, pp. 4-24. (In Russian).

56. Fainzilberg L.S., Orikhovskaya K.B. A new approach for detecting the effect of electrical heart alternation on a single-channel ECG. Bulletin of the National Technical University "KPI". 2017, no. 21 (1243), pp. 144-151. (In Russian). DOI: 10.20998/24110558.2017.21.13.

57. Gritsenko V.I., Fainzilberg L.S., Kravchenko A.N., Korchinskaya Z.A., Orikhovskaya K.B., Pasko V.S., Stanislavskaya S.S. Cognitive graphical images in the task of assessing the body's response to a load by phase printing method. Upravlâûsie sistemy $i$ mašiny. 2016, no. 6, pp. 24-33. (In Russian).

58. Fainzilberg L.S. Generalized Method of Processing Cyclic Signals of Complex Form in Multidimension Space of Patameters. Journal of Automation and Information Sciences. 2015, Vol. 47, Iss. 3, pp. 24-39. DOI: 10.1615/JAutomatInfScien.v47.i3.30

59. Fainzilberg L.S., Matushevich N.A. An effective method for analyzing diagnostic features by a noisy electrocardiogram. Upravlâûsie sistemy i mašiny. 2016, no. 2, pp.76-84. (In Russian).

60. Fainzilberg L.S., Dykach Ju.R. Linguistic approach for estimation of electrocardiograms's subtle changes based on the Levenstein distance. Cybernetics and Computer Engineering. 2019, no. 2 (196), pp. 3-26. DOI: https:// 10.15407/kvt196.02.003.

61. Fainzilberg L.S. Intellectual Information Technologies on Smartphone. Proc. of the XII International Conference "Information Technology and Automation - 2019" (Odessa, $17-18^{\text {th }}$ of Oct, 2019). Odessa, 2019, Part 1, pp. 31-33.

Received 06.12.2019

\section{ЛІТЕРАТУРА}

1. Амосов Н.М. Моделирование сложных систем. Киев: Наукова думка, 1968. 87 с.

2. Анохин П. К. Теория функциональной системы. Успехи физиологичесих наук. 1970. Том. 1. № 1. C. 19-54.

3. Grodins F.S. Control Theory and Biological Systems. New York: Columbia University Press, 1963. $179 \mathrm{p}$.

4. Гриценко В.І. Цифрова медицина та інтелектуальні інформаційні технології - основа охорони здоров’я майбутнього. Вісник НАН Украӥни. 2016. № 5. С.41-43.

5. Гриценко В.І., Файнзільберг Л.С. Персоніфіковані засоби цифрової медицини крок до здоров'я. Вісник НАН Украӥни. 2012. № 8. С. 62-70.

6. Гриценко В.И., Файнзильберг Л.С. Информационная технология ФАЗАГРАФ® для интегральной оценки состояния сердечно-сосудистой системы по фазовому портрету электрокардиограммы. Врач и информационные технологии. 2013. № 3. С. 52-63.

7. Zhang S., Liao R., Alpert J.S., Kong J., Spetzger U., Milia P., et al. Digital Medicine: Emergence, Definition, Scope and Future. Digit Medicine. 2018. No. 4. P. 1-4. DOI: 10.4103/digm.digm_9_18. 
8. Kwakkel G., Kollen B., Lindeman E.. Understanding the Pattern of Functional Recovery after Stroke: Facts and Theories. Restor Neurol Neurosci. 2004. No. 22. P. 281-299.

9. Lo A.C., Guarino P.D., Richards L.G., Haselkorn J.K., Wittenberg G.F., Federman D.G. et al. Robot Assisted Therapy for Long Term upper Limb Impairment after Stroke. The New England Journal of Medicine. 2010. Issue 362. P. 1772-1783. DOI: 10.1056/NEJMoa0911341.

10. Вовк М. И. Галян., Е. Б.,. Куцяк А. А, Лаута А. Д. Формирование индивидуального комплекса управляющих воздействий для реабилита-ции движений и речи после инсульта. Кибернетика и вычислительная техника. 2018. № 3. С. 43-63.

11. Milia P., De Salvo F., Caserio M., Cope T., Weber P., Santella C. et al. Neurorehabilitation in Paraplegic Ptients with an Active Powered Exoskeleton (Ekso). Digital Medicine. 2016. No. 2. P. 163-168. DOI: 10.4103/digm.digm_51_16.

12. Michaud F., Salter T., Duquette A., Laplante J. Perspectives on Mobile Robots as Tools for Child Development and Pediatric Rehabilitation. Assistive Technology. 2007. Vol. 19. No. 1. P. 21-36. https://doi.org/10.1080/10400435.2007.10131863

13. Сухоручкина О.Н., Прогонный Н.В., Воронов М.А. Интерпретация и использование измерений сенсора-дальномера в задачах управления автономным мобильным роботом. Управляюшие системы и машины. 2017. № 1. С. 26-34.

14. Краевский С.В., Рогаткин Д.А. Медицинская робототехника: первые шаги медицинских роботов. Технологии живых систем. 2010. Том 7. № 4. С. 3-14.

15. Okie S. Robots Make the Rounds to Ease Hospitals' Costs. The Washington Post. 2002. № 3. P. A3.

16. Тарасова Л. Да Винчи в тандеме с хирургом. Медиџинский вестник. 2008. № 8. С. 435.

17. Аврунин О.Г., Семенець В.В. К вопросу об определении силовых характеристик поля в системах магнитного стереотаксиса. Радиотехника. 2001. № 117. С.121124.

18. Wang Y., Butner S.E., Darzi A. The Developing Market for Medical Robotics. Proc. IEEE, Special issue "Medical Robotics". 2006. Vol. 94. No. 9. P.1763-1770. DOI: 10.1109/JPROC.2006.880711.

19. Donnet A., Valade D., Régis J. Gamma Knife Treatment for Refractory Cluster Headache: Prospective Open Trial. Journal of Neurology, Neurosurgery and Psychiatry. 2005. No. 2. P. 218-221. DOI: 10.1136/jnnp.2004.041202.

20. Simroid: Dentistry in the uncanny valley. - http://pinktentacle.com/2007/11/simroiddentistry-in-the-uncanny-valley-video.

21. SimMan 3G. Patient Simulator Gets a Serious Upgrade. MedGadget internet journal of emerging medical technologies.

22. Fainzilberg L.S., Pomorskaya D.V. Information technology teaching the methods for the organism recovery at home conditions. Управляющие системы и машины. 2018. № 1. C. 87-96. DOI: https://doi.org/10.15407/usim.2018.01.087.

23. Shaw D. Overview of Telehealth and Its Application to Cardiopulmonary Physical Therapy. Cardiopulmonary Physical Therapy Journal. 2009. Vol. 20. No. 2. P. 13-18.

24. Telemedicine yesterday, today, tomorrow. Electronics: Science, Technology, Business. 2000. No. 2. P. 62-65.

25. Digital medicine in Ukraine: overview of services - https://ain.ua/ 2018/12/14/cifrovaya- medicina-v-ukraine-obzor-servisov/

26. Fainsilberg L.S. Digital medicine and intellectual information technology. Proc. of the First International Scientific and Practical Conference "Information Systems and Technologies in Medicine" (ISM-2018). Kharkiv: KNURE, Madrid Printing House, 2018. P. 21-23.

27. Empowering Heroes, Transforming Health. URL: https://www.ibm.com/watson/health/

28. Технологии IBM в здравоохранении. URL: http://cognitive.rbc.ru/health-tech.

29. Ambulatory Cardiac Monitoring: Avoiding Maturity through Technological Advancement. Market Engineering Research. Frost \& Sullivan, Meriland. 2008. No. 9. P. 325.

30. Turing A.M. On Computable Numbers, with an Application to the Entscheidungsproblem. Proceedings of the London Mathematical Society. 1937. Vol. 2. Issue 42. P. 230-265.

31. McCulloch W.S., Pitts W. A Logical Calculus of the Ideas Immanent in Nervous Activity Bulletin of Marhematicak Biophysics. 1943. Vol. 5. P. 115-143. 
32. Nils Aall Barricelli N.A. Numerical Testing of Evolution Theories. Acta Biotheoretica. 1962. Vol. 16. Issue 1-2. P. 69-98.

33. Converging Technologies for Improving Human Performance: Nanotechnology, Biotechnology, Information Technology and Cognitive Science / Edited by Mihail C. Roco and William Sims Bainbridge. Dordrecht: Kluwer Academic Publishers (Springer), 2003. 482 p.

34. Файнзильберг Л.С. Интеллектуальные возможности и перспективы развития фазаграфии - информационной технологии обработки сигналов сложной формы. Кибернетика $u$ bblчислительная техника. 2016. Вып. 186. С. 56-77.

35. Файнзильберг Л.С. Интерактивный синтез информационных технологий обработки сигналов с локализованной информацией. Кибернетика и вычислительная техника. 2017. № 1 (187). С. 11-29.

36. Гриценко В.І. Інтелектуалізація інформаційних технологій. Наука і технології.. Київ: Інститут кібернетики ім. В.М. Глушкова НАН України, 1992. С. 4-9.

37. Файнзильберг Л.С. Компьютерная диагностика по фазовому портрету электрокардиограммыл. Киев: Освита Украины, 2013. 191 с.

38. Файнзильберг Л.С. Основы фазаграфии. Киев: Освита Украины, 2017. 264 с.

39. Дячук Д.Д., Гриценко В.І., Файнзільберг Л.С. и др. Застосування методу фазаграфії при проведенні скринінгу ішемічної хвороби серця. Методичні рекомендації МОЗ України № 163.16/13.17. Київ: Український центр наукової медичної інформації і патентноліцензійної роботи, 2017. 32 с.

40. Файнзильберг Л.С. Интеллектуальная информационная технология обработки сигналов с локализованной информацией. Штучний інтелект. 2018. № 2. С. 144-153.

41. Дячук Д.Д., Кравченко А.Н., Файнзильберг Л.С., Станиславская С.С., Корчинская 3.А., Ориховская К.Б., Пасько В.С., Михалев К.А. Скрининг ишемии миокарда методом оценки фазы реполяризации. Украӥнський кардіологічний журнал. 2016. № 6. С. 82-89.

42. Майданник В.Г., Хайтович Н.В., Файнзильберг Л.С., Степанов В.А., Владимирова А.А., Мисюра Л.И. Симметрия зубца Т на электрокардиограмме как маркер кардиометаболического риска у школьников. Международный журнал педиатрии, акушерства и гинекологии. 2013. Т. 4. № 3. С. 35-39.

43. Морозик А.А. Файнзильберг Л.С. Диагностическая значимость сочетанного анализа электрокардиосигнала на фазовой плоскости и вариабельности ритма сердца у детей с диабетической кардиопатией. Международный журнал педиатрии, акушерства и гинекологии. 2015. Т. 7. № 1. С. 11-17.

44. Морозик А.О, Майданник В.Г., Файнзільберг Л.С. Інформативні властивості показників фази реполяризації одноканальної електрокардіограми в дітей із діабетичною кардіоміопатією. Ендокринологія. 2018. Том 23. № 1. С. 74-82.

45. Майданник В.Г, Файнзильберг Л.С., Дуккарт К.Б, Морозик А.О., Кондратюк А.С. Регуляторные паттерны в оценке функционального состояния организма детей и подростков с сахарным диабетом 1 типа. Український журнал дитячої ендокринології. 2018. № 1. С. 51-60.

46. Майданник В.Г., Файнзильберг Л.С., Дуккарт К.Б., Морозик А.А., Кондратюк А.С. Новый подход к анализу функционального состояния организма детей и подростков с сахарным диабетом 1 типа. Современная педиатрия. 2018. № 2(90). С. 37-46.

47. Павличенко П.П. Влияние игровой нагрузки на функциональное состояние профессиональных футболистов. Світ медицини та біологіï. 2015. № 1(48). С. 49-54.

48. Fainzilberg L.S. New Opportunities of Phasegraphy in Medical Practice. Science and Innovation. 2017. Vol. 13. Issue 3. P. 37-50. DOI: 10.15407/scine13.03.037.

49. Файнзильберг Л.С. Оценка эффективности применения информационной технологии ФАЗАГРАФ $\Phi^{\circledR}$ по данным независимых исследований. Управляющие системы $u$ матины. 2014. № 2. С. 84-92.

50. Файнзильберг Л.С. Технология построения телемедицинской системы на основе генеративной модели порождения искусственной ЭКГ реалистической формы. Клиническая информатика и телемедицина. 2012. Т.8. Вып. 9. С. 89-98.

51. Файнзильберг Л.С., Сорока Т.В. Разработка телемедицинской ситемы для дистанционного мониторирования сердечной деятельности на основе метода фазаграфии. Восточно-Европейский журнал передовых технологий. 2015. № 6/9(78). С. 37-46. 
52. Файнзильберг Л.С., Сорока Т.В. Мобильные приложения для виртуального взаимодействия врача и пациента при дистанционном мониторинге сердечной деятельности. Кибернетика и вычислительная техника. 2016. Вып. 184. С. 8-24.

53. Fainzilberg L.S., Potapova T.P. Computer Analysis and Recognition of Cognitive Phase Space Electro-Cardio Graphic Image. Proceeding of the 6th International Conference On Computer analysis of Images and Patterns (CAIP'95). Prague (Czech Republic). 1995. P. 668-673.

54. Файнзільберг Л.С., Корчинська З.А., Семергей М.О. Програмно-технічний комплекс для дослідження нового методу біометричної ідентифікації особистості за фазовим портретом ЕКГ. Криміналістичний вісник. 2015. № 1(23). С. 63-71

55. Файнзильберг Л.С., Ориховская К.Б, Ваховский И.В. Оценка хаотичности формы фрагментов одноканальной электрокардиограммы. Кибернетика и вычислительная техника. 2016. Вып. 183. С. 4-24.

56. Файнзильберг Л.С., Ориховская К.Б. Новый подход к обнаружению эффекта электрической альтернации сердца по одноканальной ЭКГ. Вісник Національного технічного університету «ХПI». 2017. № 21 (1243). С. 144-151.

57. Гриценко В.И., Файнзильберг Л.С., Кравченко А.Н., Корчинская 3.А., Ориховская К.Б, Пасько В.С., Станиславская С.С. Когнитивные графические образы в задаче оценки реакции организма на нагрузку методом фазаграфии. Управляющие системы и машины. 2016. № 6. С. 24-33.

58. Fainzilberg L.S. Generalized Method of Processing Cyclic Signals of Complex Form in Multidimension Space of Patameters. Journal of Automation and Information Sciences. 2015. Vol. 47. Issue 3. P. 24-39. DOI: 10.1615/JAutomatInfScien.v47.i3.30

59. Файнзильберг Л.С., Матушевич Н.А. Эффективный метод анализа диагностических признаков по зашумленной электрокардиограмме. Управляющие системы $u$ машины. 2016. № 2. С.76-84.

60. Fainzilberg L.S., Dykach Ju.R. Linguistic approach for estimation of electrocardiograms's subtle changes based on the Levenstein distance. Cybernetics and Computer Engineering. 2019. No. 2 (196). P. 3-26. DOI: https:// 10.15407/kvt196.02.003.

61. Fainzilberg L.S. Intellectual Information Technologies on Smartphone. Proc. the XII International Conference "Information Technology and Automation - 2019" (Odessa, October, 17-18, 2019). Part 1. P. 31-33.

Отримано 06.12.2019 
Гриценко B.I., член-кореспондент НАН України, директор Міжнародного науково-навчального центру інформаційних технологій та систем

НАН України та МОН України

e-mail: vig@irtc.org.ua

Файнзильберг Л.С., д-р техн. наук, професор, голов. наук. співроб.

відд. інтелектуальних автоматичних систем

e-mail: fainzilberg@gmail.com

Міжнародний науково-навчальний центр інформаційних технологій та систем НАН України та МОН України, пр. Акад. Глушкова 40, м. Київ, 03187, Україна

\section{СУЧАСНИЙ СТАН І ПЕРСПЕКТИВИ РОЗВИТКУ ЦИФРОВОЇ МЕДИЦИНИ}

Вступ. Згідно з означенням Міжнародної асоціації цифрової медицини, цифровою медициною $є$ галузь науки, в якій вчені прагнуть пояснити раніше незрозумілі патофізіологічні явища в організмі людини і досліджувати нові медичні процедури з використанням сучасних цифрових технологій для поліпшення якості життя людини.

Мета статті - надати коротку інформацію про сучасний стан і перспективи розвитку засобів цифрової медицини.

Методи. Проведено аналіз основних напрямів цифрової медицини. Сформульовано базові означення понять «Інтелектуальна IT оброблення сигналів» та «Ефективна обчислювальна процедура». На прикладі методу фазаграфії продемонстровано роль інтелектуальних IT в цифровій медицині.

Результати. Наявні методи і засоби цифрової медицини застосовують для діагностики, лікування, реабілітації, а також для відновлення втрачених функцій пацієнта (зір, слух, рух). Такі технології дають змогу не тільки звільнити медичних працівників від виконання рутинних завдань, а й підвищити ефективність виконання хірургічних операцій, променевої терапії та ряду інших складних завдань практичної медицини.

На відміну від традиційних IT, основаних на процедурах оброблення числових даних, інтелектуальні IT оперують узагальненими поняттями (образами), що дають повнішу інформацію про зовнішнє середовище, а аналіз таких образів породжує цілісну картину досліджуваних явищ.

В рамках алгоритмічного підходу побудова інтелектуальних IT для вирішення завдань цифрової медицини передбачає активну участь розробника технології, який, застосовуючи свій природний інтелект, створює ефективні процедури для одержання діагностичної інформації з реальних даних, спотворених збуреннями.

Висновки. Інтелектуальні IT, які мають властивості природного інтелекту (адаптація, узагальнення, здатність до навчання та ін.), відіграють важливу роль у розширенні функціональних можливостей і підвищення ефективності засобів цифрової медицини.

Ключові слова: цифрова медицина, інтелектуальні IT, ефективні обчислювальні процедури. 
Гриценко В.И., член-корреспондент НАН Украины, директор Международного научно-учебного центра информационных технологий и систем

НАН Украины и МОН Украины

e-mail: vig@irtc.org.ua

Файнзильберг Л.С., д-р техн. наук, профессор,

глав. науч. сотр.

отд. интеллектуальных автоматических систем

e-mail: fainzilberg@gmail.com

Международный научно-учебный центр информационных

технологий и систем НАН Украины и МОН Украины,

пр. Акад. Глушкова, 40, г. Киев, 03187, Украина

\section{СОВРЕМЕННОЕ СОСТОЯНИЕ И ПЕРСПЕКТИВЫ РАЗВИТИЯ ЦИФРОВОЙ МЕДИЦИНЫ}

Введение. Согласно определению Международной ассоциации цифровой медицины, цифровой медициной называют область науки, в которой ученые стремятся объяснить ранее непонятные патофизиологические явления в организме человека и исследовать новые медицинские процедуры с использованием современных цифровых технологий для улучшения качества жизни человека.

Цель статьи - дать краткую информацию о современном состоянии и перспективах развития средств цифровой медицины.

Методы. Проводится анализ основных направлений цифровой медицины. Формулируются базовые определения понятий «Интеллектуальная ИТ обработки сигналов» и «Эффективная вычислительная процедура». На примере метода фазаграфии демонстрируется роль интеллектуальных ИТ в цифровой медицине.

Результаты. Существующие методы и средства цифровой медицины применяют для диагностики, лечения, реабилитации, а также для восстановления утраченных функций пациента (зрение, слух, движение). Такие технологии позволяют не только освободить медицинских работников от решения рутинных задач, но и повысить эффективность выполнения хирургических операций, лучевой терапии и ряда других задач практической медицины.

В отличие от традиционных ИТ, основанных на процедурах обработки числовых данных, интеллектуальные ИТ оперируют обобщенными понятиями (образами), дающими более полную информацию о внешней среде, а анализ таких образов порождает целостную картину изучаемых явлений.

В рамках алгоритмического подхода построение интеллектуальных ИТ для решения задач цифровой медицины предполагает активное участие разработчика технологии, который, применяя свой естественный интеллект, создает эффективные процедуры для извлечения диагностической информации из реальных данных, искаженных возмущениями.

Выводы. Интеллектуальные ИТ, обладающие свойствами естественного интеллекта (адаптация, обобщение, обучаемость и др.), играют важную роль в расширении функциональных возможностей и повышении эффективности средств цифровой медицины.

Ключевые слова: цифровая медицина, интеллектуальные ИТ, эффективные вычислительные процедуры. 